\title{
Adenovirus pulmonary infections identified by PCR and in situ hybridisation in bone marrow transplant recipients
}

T Matsuse, H Matsui, C-Y Shu, T Nagase, T Wakabayashi, S Mori, S Inoue, Y Fukuchi, H Orimo

\begin{abstract}
Aims-To investigate adenovirus pulmonary infections in bone marrow transplant (BMT) recipients.

Methods-Formalin fixed, paraffin wax embedded lung tissue was examined from 13 necropsy cases after BMT using PCR and in situ hybridisation to detect adenovirus DNA. The E1A region of the adenoviral genome was targeted for PCR. In situ hybridisation was performed only in the PCR positive cases.

Results-Of the 13 lung specimens analysed, nine cases were negative for adenoviral nucleic acid. Four (30\%) PCR and two $(15 \%)$ in situ hybridisation positive cases were found. In some of the patients there were clinical and pathological indications that some diseases might be associated with adenovirus infection-haemorrhagic cystitis (three cases); necrotising pneumonia (one case). In necrotising pneumonia in which no pathogenic agents had been shown by conventional histological study, the in situ hybridisation technique showed positive staining for adenovirus. In a patient who died of renal failure caused by adenovirus nephritis, both PCR and in situ hybridisation were positive in the lung as
\end{abstract}

Table 1 Clinical and pathological findings in transplant recipients

\begin{tabular}{|c|c|c|c|c|c|}
\hline $\begin{array}{l}\text { Case } \\
\text { No }\end{array}$ & Sex & Age & $\begin{array}{l}\text { Basal } \\
\text { haematological } \\
\text { disorder }\end{array}$ & Pulmonary lesions & $\begin{array}{l}\text { Survival } \\
\text { period after } \\
B M T \text { (days) }\end{array}$ \\
\hline 1 & $\mathbf{M}$ & 38 & AA & Aspergillosis & 74 \\
\hline $\begin{array}{l}2 \\
3\end{array}$ & $M$ & 18 & MDS & Bacterial pneumonia & 5 \\
\hline & & & & $\begin{array}{l}\text { Fungus, ĆMV } \\
\text { pneumonia }\end{array}$ & 92 \\
\hline 4 & $\mathbf{M}$ & 33 & AMMoL & Aspergillosis & 4 \\
\hline 5 & $\mathbf{F}$ & 48 & AMMoL & $\begin{array}{l}\text { Pulmonary } \\
\text { haemorrhage }\end{array}$ & 76 \\
\hline 6 & F & 33 & MDS & Bacterial pneumonia & 77 \\
\hline 7 & $\mathbf{M}$ & 46 & CML & Blast cell invasion & 288 \\
\hline 8 & & 23 & NHL & Lymphoma cell & 77 \\
\hline 9 & $\mathbf{M}$ & 10 & ALL & None & 24 \\
\hline 10 & $\mathbf{M}$ & 35 & MDS & None & 209 \\
\hline 11 & $\mathbf{M}$ & 42 & CML & $\begin{array}{c}\text { Haemorrhagic } \\
\text { necrotising }\end{array}$ & 308 \\
\hline 12 & $\mathbf{M}$ & 36 & ALL & Acute interstitial & 20 \\
\hline 13 & $\mathbf{M}$ & 37 & CML & $\begin{array}{l}\text { pneumonia } \\
\text { CMV, Candida sp } \\
\text { pneumonia }\end{array}$ & 88 \\
\hline
\end{tabular}

$\mathrm{AA}=$ aplastic anaemia; $\mathrm{MDS}=$ myelodysplastic syndrome; $\mathrm{ALL}=$ acute lymphocytic leukaemia; $\mathrm{AMMOL}=$ acute myelomonocytic leukaemia; $\mathrm{CML}=$ chronic myelocytic leukaemia; NHL = non-Hodgkin's lymphoma.

well as in the kidney, although no histological change was found. Two PCR positive cases lacked positive sites for adenovirus by in situ hybridisation.

Conclusions-The combination of PCR and in situ hybridisation could be useful for diagnosing adenovirus infection of the lung in BMT recipients. These results provide a basis for exploring further the clinical use of PCR and in situ hybridisation to diagnose adenovirus infection.

(F Clin Pathol 1994;47:973-977)

Adenovirus lytic infection in immunosuppressed patients can cause systemic infections and present a variety of clinical manifestations ranging from broncho-bronchiolitis to interstitial pneumonia, necrotising pneumonia, hepatitis, colitis, and haemorrhagic cystitis. ${ }^{1-9}$ In 1985 Shields et al reported that after bone marrow transplantation (BMT) the incidence of adenovirus infection was $4.9 \%$ and invasive infection $1 \% .^{10}$ Diagnosis has been made mainly from isolation of the virus or an increase in antibody titre in addition to the characteristic adenovirus inclusion bodies seen on histological examination. However, it takes several days to isolate adenovirus from clinical specimens and the sensitivity is not very high. As latent adenovirus occurs in lymphocytes, lung, tonsils, and adenoids, ${ }^{11-14}$ isolation from one site does not always mean systemic infection. Additionally, a low antibody titre does not rule out adenovirus infection in some immunosuppressed subjects ${ }^{15}$; and adenoviral inclusions could be mistaken for other viral bodies.

Like cytomegalovirus (CMV), latent adenovirus is thought to be reactivated in some conditions. It would therefore be of clinical use to differentiate latent from active infection in BMT recipients with a highly specific method. We tested the combination of the polymerase chain reaction (PCR) and in situ hybridisation (ISH) for this purpose. PCR can detect latent adenovirus infection with low copy numbers. ${ }^{11}$ Only in the acute and active phase can adenovirus infection be demonstrated with ISH. ${ }^{716}$ Positive PCR results merely mean the presence of viral nucleic acid. Compatible pathological findings, positive 
Table 2 Results of adenovirus PCR and in situ hybridisation with associated clinical and pathological findings

\begin{tabular}{|c|c|c|c|c|c|c|c|}
\hline $\begin{array}{l}\text { Case } \\
\text { No }\end{array}$ & $\begin{array}{l}\text { Necrotising } \\
\text { pneumonia }\end{array}$ & Colitis & Hepatitis & $\begin{array}{l}\text { Haemorrhagic } \\
\text { cystitis }\end{array}$ & $\begin{array}{l}\text { Adenovirus } \\
\text { isolation } \\
\text { (organ) }\end{array}$ & $P C R$ & $\begin{array}{l}\text { In situ } \\
\text { hybridisation }\end{array}$ \\
\hline 1 & - & - & + & + & + (urine) & + & - \\
\hline 2 & - & - & - & - & - & - & ND \\
\hline 3 & - & + & - & + & - & - & ND \\
\hline 4 & - & - & - & - & - & - & ND \\
\hline 5 & - & - & - & - & - & - & ND \\
\hline 6 & - & - & - & - & - & - & ND \\
\hline 7 & - & - & - & - & - & - & ND \\
\hline 8 & - & - & - & - & - & - & ND \\
\hline 9 & - & - & - & - & - & + & - \\
\hline 10 & - & - & - & + & + (urine) & + & + \\
\hline 11 & + & - & - & - & - & + & + \\
\hline 12 & - & - & - & - & - & - & ND \\
\hline 13 & - & - & + & - & - & - & ND \\
\hline
\end{tabular}

PCR, and in situ hybridisation results indicate active adenovirus infection.

\section{Methods}

Lung tissue obtained from 13 consecutive necropsy cases, who died within one year of BMT between 1986 and 1991 at the Institute of Medical Science, University of Tokyo, were studied. The clinical histories of these patients are shown in table 1. Adenovirus was isolated from the urine of cases 1 and 10 (table 2). Some of the cases had the pathological manifestations compatible with adenovirus infection, including haemorrhagic cystitis, hepatitis, necrotising pneumonia, and colitis (table 2). However, adenovirus infection was not demonstrated histologically except in case 10 who had a renal infection with adenovirus inclusion bodies. This patient had died of renal failure caused by adenovirus nephritis. The kidney sample from this case served as a positive control for PCR and in situ hybridisation.

DNA extraction was performed according to a method described before. ${ }^{17}$ The DNA extracted from paraffin wax embedded tissues was analysed by PCR targeted at the E1A region of adenovirus. As a positive control, DNA was extracted from formalin fixed, paraffin wax embedded Graham 293 cells, transformed with four to five copies of E1A region of the adenovirus type 5 genome. ${ }^{18}$

PCR was performed using our previously described method. ${ }^{11}$ Thirteen lung and one renal sample were examined simultaneously along with the positive and negative controls. For PCR, adenovirus type 2 DNA (5 ng) served as a positive control in addition to the DNA extracted from Graham 293 cells. "No template DNA," which consisted of a sample containing all the components for PCR except template DNA, served as a negative control. The oligonucleotide primer was chosen from the E1A region of adenovirus types 2 and 5 genomes, according to the sequences in the Genebank DNA database. " The primer

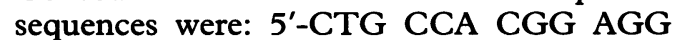
TGT TAT TACC-3' and 3'-TCC AGG ACA CAG ACT TGG ACTC-5' . After PCR, $20 \mu$ l of the PCR mixture was subjected to $1 \%$ agarose gel electrophoresis. The amplification products were transferred to a nylon mem- brane (Hybond-N, Amersham, Illinois, USA) by diffusion blotting in $20 \times$ SSC ( $3 \mathrm{M}$ sodium chloride, $0.3 \mathrm{M}$ sodium citrate, $\mathrm{pH} 7 \cdot 0$ ). The filter was prehybridised at $65^{\circ} \mathrm{C}$ for five hours in $6 \times$ SSC, $5 \times$ Denhardt's solution, $0.5 \%$ sodium dodecyl sulphate (SDS), and 20 $\mu \mathrm{g} / \mathrm{ml}$ of salmon sperm DNA. The radiolabelled probe was added to the filter and hybridised at $65^{\circ} \mathrm{C}$. The filter was washed twice at room temperature for 10 minutes in $2 \times$ SSC, $0.1 \%$ SDS; then at $65^{\circ} \mathrm{C}$ for $30 \mathrm{~min}-$ utes in $0 \cdot 1 \times$ SSC, $0 \cdot 1 \%$ SDS. The filter was then subjected to autoradiography. The probe DNA for the E1A region was a 756 base pair product of a double digest with Pst I and BamH I of a 742 base pair Alu I fragment from $\mathrm{pXC}-15$ containing the $\mathrm{E} 1 \mathrm{~A}$ region which had been subcloned into the Hinc II site of pUC13 (gift of Dr JC Hogg, Vancouver, Canada). This 756 base pair fragment was purified by low melting agarose gel electrophoresis and labelled with ${ }^{32} \mathrm{P}$-dCTP using a random priming kit (Amersham).

In situ hybridisation analysis was performed only for the PCR positive cases. Four PCR positive lung and one kidney (from case 10) samples were examined. For each sample, two identical sections were put on a slide coated with poly-L-lysine. One side was hybridised with adenovirus DNA probe using the ENZO PathoGene DNA probe assay for the identification of adenovirus (ENZO Diagnostics, New York, USA), the other side served as a control and was hybridised with biotinylated pBR 322 DNA. In situ hybridisation was performed according to the manufacturer's instructions. The presence of hybridised probe was determined by the reaction of hydrogen peroxide and 3-amino-9ethylcarbazole.

Cultured Hep-II cells infected with adenovirus types 2 and 5 served as the positive control. They were fixed with formalin and embedded in paraffin wax.

\section{Results}

The PCR product was subjected to Southern blotting after electrophoresis, and probed with radiolabelled DNA from the corresponding region of the adenovirus genome. The expected size of the amplified products was 675 base pairs. The autoradiograph result of $P C R$ for the E1A region is shown in fig 1 . The DNA extracted from cases $1,9,10$, and 11 (30\%) was positive for the E1A region by PCR, as were the positive controls (table 2). The positive controls consisted of $5 \mathrm{ng}$ of adenovirus type 2 genomic DNA and the extracted DNA from paraffin wax sections of Graham 293 cells, and the kidney sample with adenovirus inclusion bodies. The negative control "no template DNA" did not show bands either in the gel or the autoradiograph.

Figure 2A shows that the cultured cells infected with adenovirus type 5 positively stained for adenovirus with in situ hybridisation as well as the cultured cells infected with adenovirus type 2 . Among the four PCR positive cases, two (cases 10 and 11) (15\%) 
Figure 1 Autoradiograph of Southern hybridisation of PCR products probed with adenovirus $E 1 A$ region. Thirteen samples from necropsy cases and two positive (Adeno virus, Kidney 10) and one negative (No template) control samples are hybridised with ${ }^{32} \mathrm{P}$ labelled probe. Lanes from top to bottom are PCR products from "No template"

$D N A, 5$ ng of adenovirus type 2 DNA, DNA extracted from lungs (BMT cases 1 to 13) and one kidney (BMT case 10). Cases 1, 9, 10, and 11 were hybridised with the prove for the $E 1 A$ region as well as two positive controls.

"No template" = no template DNA; Adeno virus $=5$ ng of adenovirus DNA, Kidney $10=$ kidney sample from case 10.

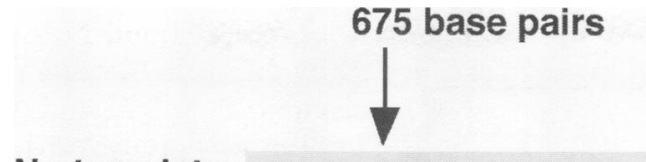

No template •

\section{Adeno virus}

Case
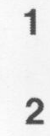

3

3

4

5

6

7

8

9

10

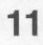

12

13

Kidney 10

stained positively on situ hybridisation for adenovirus (fig 2B); the others did not. All four PCR positive samples were not hybridised with non-specific DNA (biotinylated pBR322) probe, a step included for negative controls (fig 2C). Both the lung and kidney specimens from case 10 showed positive results with PCR and in situ hybridisation. Case 11 was diagnosed as having haemorrhagic necrotising pneumonia. However, the causal agent was not known because a specific feature had not been histologically demonstrated and no pathogen had been clinically isolated. We found sites positively stained with adenovirus DNA probe by in situ hybridisation in the lesions showing necrotising haemorrhagic pneumonia (case 11), but the positive cells were scattered throughout.

Discussion

Patients immunocompromised as a result of immunosuppressive treatment, organ transplantation, or chemotherapy are increasing in number, as are those with AIDS. In such patients viral pulmonary infections have become one of the most important causes of death. However, viral infection in the lung is difficult to distinguish from other interstitial pulmonary disorders, such as drug toxicity, neoplasia, pulmonary haemorrhage, allergic reactions, and pulmonary oedema. ${ }^{19}$ Besides, it is difficult to determine which species of virus is responsible for the lesion with or without viral inclusion bodies.

The incidence of adenovirus infections after BMT has been based on the clinical isolation of the virus, the prevalent serotypes being adenovirus types $1,2,5,7,11,34$, and $35 .{ }^{10}$ However, the isolation rate is not an indicator of the morbidity. To diagnose invasive infections, samples of the diseased organs for culture and histological examination are needed; and these should not be highly specific and sensitive.

Polymerase chain reaction (PCR) and in situ hybridisation for detecting viral nucleic acid have been established for the diagnosis of several viral infections. However, the sensitivity of PCR is extremely high, and positive PCR results merely indicate the presence of the viral genome, and not necessarily that the virus is related to the present disease. In this study the E1A region of the adenoviral genome was targeted by the PCR method. The E1A gene can sensitise cells to destruction by cytokine ${ }^{20}$ and it could have an essential role in adenovirus infection through activation of other adenoviral genomic DNA. ${ }^{21}$ The sensitivity of in situ hybridisation for the detection of adenoviral genome has been reported before. ${ }^{16} \mathrm{~A}$ detection limit of five to 10 copies of adenoviral DNA using in situ hybridisation has been estimated, and adenovirus was demonstrated by in situ hybridisation only in acute cases of adenovirus pneumonia. ${ }^{16}$

We examined adenovirus infections in necropsy lung specimens from 13 necropsy patients after BMT using PCR and in situ hybridisation techniques, because adenovirus pneumonia is one of the most common causes of mortality in transplant recipients. Some of our cases had some pathological evidence suggestive of adenovirus infection: necrotising pneumonia $(n=1)$; colitis $(n=1)$; hepatitis $(n=1)$; and haemorrhagic cystitis $(n=3)$ (table 2). In this study organs other than the lungs were not examined.

In our cases the clinical isolation rate of adenovirus was $15 \%$ and the incidence of adenovirus detection by PCR was $30 \%$ in the patients who died after BMT (table 2). Both were higher than previously reported rates of adenovirus infection. ${ }^{10}$ This finding should be interpreted with caution, because the number of subjects we studied was small. However, this difference might be explained by the fact that we examined only necropsy cases and that PCR was more sensitive than isolation of the virus. PCR analysis was positive in two of the three patients with haemorrhagic cystitis 


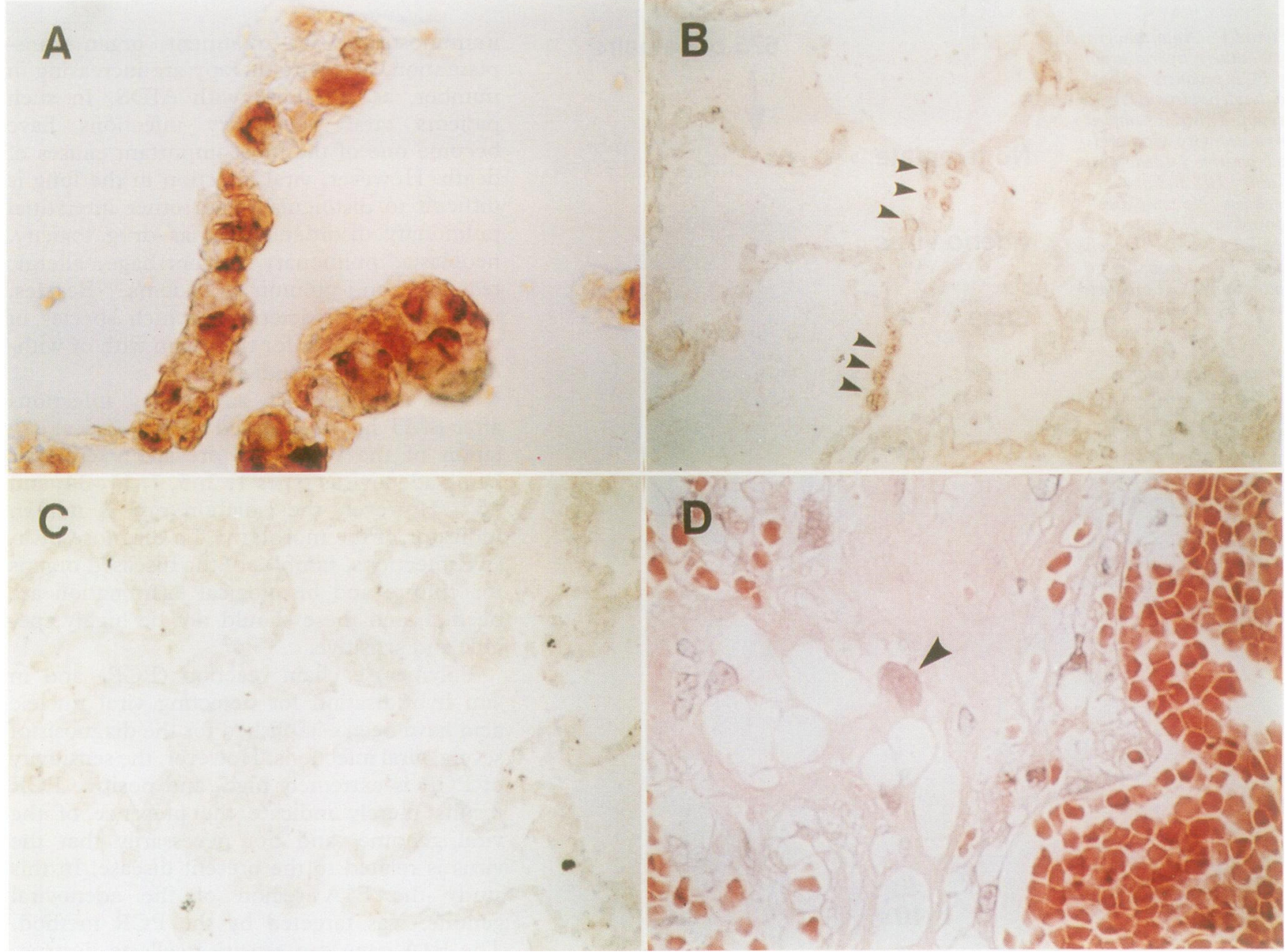

Figure 2 In situ hybridisation with biotinylated probe to the sections of formalin fixed, paraffin wax embedded lung tissue and cultured cells. $A$ Hybridisation of adenovirus probe to cultured Hep-II cells infected with adenovirus type 5 . B Hybridisation with the biotinylated

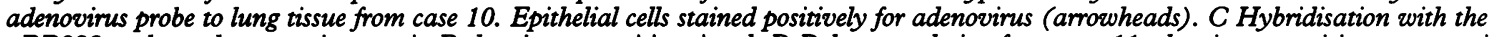
pBR322 probe to the same tissue as in $B$ showing no positive signal. D Pulmonary lesion from case 11 , showing necrotising pneumonia with haematoxylin and eosin staining. The arrowhead indicates a nucleus with an homogeneously basophilic appearance, so-called ground glass appearance, which was thought to be an adenovirus inclusion body (haematoxylin and eosin stain).

(cases 1 and 10), one patient with necrotising pneumonia (case 11), and one without any clinical and pathological findings related to adenovirus (case 9). Because PCR is highly sensitive for the detection of a viral genome, the positive PCR results do not necessarily indicate active viral infection. Therefore, the in situ hybridisation study was performed in these PCR positive cases.

Of the four positive PCR cases, two were also positive on in situ hybridisation. The lung section from the patient with necrotising pneumonia stained positively on in situ hybridisation. The PCR and in situ hybridisation findings, taken together with the clinical and histological data, indicate that the necrotising pneumonia was caused by adenovirus. However, the in situ hybridisation positive cells were scattered throughout the lesions. This is probably because the lesion was necrotic and the normal lung structure had been destroyed. As a result, the number of infected but viable and well preserved epithelial cells had decreased.

After the in situ hybridisation method had disclosed adenovirus in the lung tissue, we reexamined haematoxylin and eosin stained sections and were able to point out cells with viral inclusion bodies in the lung tissue of the case with necrotising pneumonia (case 11) (fig 2D). Definite diagnosis of active adenovirus infection can be established, if histological findings correlate with positive staining on in situ hybridisation.

In conclusion, our results raise the possibility that in addition to conventional histological and virological investigations, the combination of PCR and in situ hybridisation might be useful for detecting and diagnosing adenovirus infections in patients undergoing BMT. Further study with larger numbers of subjects is needed to evaluate the sensitivity and clinical value of these techniques.

We thank Dr JC Hogg for cloned plasmid DNA, and $\mathrm{Mr} \mathrm{H}$ Onoda for his excellent technical assistance.

Supported in part by grants from the Ministry of Education Science and Culture of Japan, Grant No 04770460.

1 Landry ML, Fong CKY, Neddermann K, Solomon L. Disseminated adenovirus infection in an immunocompromised host. Am $\mathcal{F}$ Med 1987;83:555-9.

2 Krilov LR, Rubin LG, Frogel M, Gloster E, Ni K, Kaplan $M$, et al. Disseminated adenovirus infection with hepatic necrosis in patients with human immunodeficiency virus infection and other immunodeficiency states. Rev Infect Dis 1990;12:303-7.

3 Janoff EN, Orenstein JM, Manischewitz JF, Smith PD. Adenovirus colitis in the acquired immunodeficiency syndrome. Gastroenterology 1991;100:976-9.

4 Cunningham AL, Grohman GS, Harkness J, Law C, Marriott D, Tindall B, et al. Gastrointestinal viral infecMarriott D, Tindall B, et al. Gastrointestinal viral infections in homosexual men who were symptomatic and Dis 1988;158:386-91. 
5 Numazaki $Y$, Kumasaka $T$, Yano $N$, Yamanaka $M$ Miyazawa T, Takai S, et al. Further study of acute hemMiyazawa T, Takai S, et al. Further study of acute hemorrhagic cystitis due to

$\mathcal{F}$ Med 1973;289:344-7.
Becroft DMO. Histopathology of fatal adenovirus infection of the respiratory tract in young children. $f \mathrm{Clin}$ Pathol 1967;20:561-9.

7 Abbondanzo SL, English CK, Kagan E, McPherson RA. Fatal adenovirus pneumonia in a newborn identified by electron microscopy and in situ hybridization. Arch Pathol Lab Med 1989;113:1349-53.

8 Ushijima H, Eshita Y, Araki K, Shinozaki T, Togo T, Matsunaga Y. A study of adenovirus gastroenteritis in the Tokyo area. Eur $₹$ Pediatr 1988;147:90-2.

9 Janner D, Petru M, Deborah B, Azimi PH. Fatal adenovirus infection in a child with acquired adenovirus infection in a child with acquired 434-6.

10 Shields AF, Hackman RC, Fife KH, Corey L, Meyers JD Adenovirus infections in patients undergoing bonemarrow transplantation. $N$ Engl $f$ Med 1985;312: 529-33.

11 Matsuse T, Hayashi S, Kuwano K, Keunecke H, Jefferies WA, Hogg JC. Latent adenoviral infection in the pathogenesis of chronic airway obstruction. Am Rev Respir Dis 1992;146:177-84.

12 Horwitz MS. Adenoviruses. In: Fields BN, ed. Virology. 2nd edn. New York: Raven Press, 1990:1723-40.

13 Neumann R, Genersch E, Eggers HJ. Detection of adenovirus nucleic acid sequences in human tonsils in the absence of infectious virus. Virus Res 1987;7:93-7.
14 Horvath J, Palkonyay L, Weber J. Group C adenovirus DNA sequences in human lymphoid cells. $\mathcal{f}$ Virol 1986; 59:189-92.

15 Horwitz MS, Valderrama G, Hatcher V, Korn R, deJohn $P$, Spigland I. Characterization of adenovirus isolates from AIDS patients. Ann NY Acad Sci 1984;437: 161-74.

16 Hogg JC, Irving WL, Porter H, Evans M, Dunnill MS, Fleming $\mathrm{K}$. In situ hybridization studies of adenovira infections of the lung and their relationship to follicular bronchiectasis. Am Rev Respir Dis 1989;139:1531-5.

17 Impraim CC, Saiki RK, Erlich HA, Teplitz RL. Analysis of DNA extracted from formalin-fixed, paraffin-embedded tissues by enzymatic amplification and hybridization with sequence specific oligonucleotides. Biochem Biophys Res Commun 1987;142:710-6.

18 Graham FL, Smiley J, Russel WC, Nairn R. Characteristics of a human cell line transformed by DNA from human adenovirus type 5. $f$ Gen Virol 1977;36: 59-72.

19 Heurlin N, Brattstroem C, Loennqvist B, Westman L Lidman C, Andersson J. Aetiology of pulmonary diseases in immunocompromised patients. Eur Respir $\mathcal{f}$ 1991;4:10-8.

20 Duerksen-Hughes P, Wold WSM, Gooding LR Adenovirus E1A renders infected cells sensitive to cytolysis by tumor necrosis factor. F Immunol 1989;143: 4193-200.

21 Shenk T, Flint J. Transcriptional and transforming activities of the adenovirus E1A proteins. Adv Cancer Res 1991; $57: 47-85$. 